\title{
Exploration Potential of Coalbed Methane in Karaganda Field
}

\author{
Dilda Kenzhekhanovna Sabitova ${ }^{1}$ \\ ${ }^{1}$ Kazakh-British Technical University, Almaty, Kazakhstan \\ Correspondence: Dilda Kenzhekhanovna Sabitova, Kazakh-British Technical University, Almaty, 050000, \\ Kazakhstan. E-mail: dilda.sabitova@gmail.com
}

Received: November 27, 2014

Accepted: December 7, 2014 Online Published: May 30, 2015

doi:10.5539/mas.v9n6p145

URL: http://dx.doi.org/10.5539/mas.v9n6p145

\begin{abstract}
The problematics of the economic and technological state of the prospects for coalbed methane in the Karaganda coal basin has been outlined. Therefore, correspondently the current state of development of coalbed methane in the modern world economic infrastructure of the fossil fuels and energy generating complexes has been analyzed. The main emphasis of the article has been drawn to identify forward-looking and timely development of this area, which may be designated a priority in the transition of the energy sector of Kazakhstan to the "green economy," with the current requirements of environmental safety.
\end{abstract}

Keywords: coalbed methane, coal, deposit, Karaganda basin, green economy, environment

\section{Introduction}

Kazakh government aims to diminish the degradation of natural resources with the newly established Concept of transition towards "green economy" (The Presidential Decree, 2013). This policy is focused on the efficient usage of all natural resources and their reasonable and appropriate distribution. It is very crucial to exploit coal gas in a sensible and clever way.

Coalbed methane is considered a fuel with high-performance and clean structure (in comparison to coal). There are two major methods to extract coalbed methane: as self contained/ singular fossil and as a byproduct from preliminary degassing of mines. According to statistics, there are ten countries, which have reserves of large coalbed methane: Russia -78 trillion $\mathrm{m}^{3}$, USA - 60 trillion $\mathrm{m}^{3}$, China - 28 trillion $\mathrm{m}^{3}$, Australia - 22 trillion $\mathrm{m}^{3}$, India - 18 trillion $\mathrm{m}^{3}$, Germany - 16 trillion $\mathrm{m}^{3}$, South Africa - 13 trillion $\mathrm{m}^{3}$, Kazakhstan -8 trillion $\mathrm{m}^{3}$, Ukraine - 8 trillion $\mathrm{m}^{3}$, Poland -3 trillion $\mathrm{m}^{3}$ (Alekseyev et al., 2010).

Kazakhstan is one of the countries with a big stock of energy resources. On the other hand, all these energy resources are not allocated efficiently across the whole country (economic and geographic locations). Although the largest industrial centers are based in the eastern and north-eastern regions, the main oil and gas reserves are focused in the western part of Kazakhstan. Central regions are famous for their huge coal resources. Serious environmental problem has arisen in this area due to the actively happening processes of burning coal and associated gas. Apart from the central region, other regions are experiencing a significant energy shortage. Lowered railway tariff rate is negatively influencing coal's competitiveness as it takes a long time to deliver it.

Following article conducts an overview of possibility of CBM production in Karaganda basin based on geological conditions of the current state of the basin, environmental and economical assessment, feasibility study.

\subsection{State of the Problem}

Nowadays there is a large number of published materials concerned with advanced coalbed methane production technologies, the use/appliance of various gels, expanded liquids, carbon dioxide, nitrogen, near well bore's loading-out, cavitation's mode on the basis of cyclical air hydro-impulse technologies etc. (Honglin et al., 2011). Special attention is given to technologies used with low-permeable layers of coal. Even though, the main geological and geophysical research in Karaganda basin were carried out in 1970s and '80s under the system of Soviet Union (Golitsyn et al., 1973), the scientists of Kazakhstan are updating the geological base considering existing coal mining in Karaganda basin. Also, a special attention is paid to the methods of coal's preliminary draining out of gases (provision of methane's security). Besides that, the Constituent contract was signed between the public company "KazTransGaz" (national operator) and group of companies LeMar CA Inc. on 
opening a joint venture for the realization of the methane's exploration and mining investment project Karaganda coal basin. Taking into account this the author truly believes that the current research will meet a certain interest amongst relevant and general public.

\subsection{Importance of the Problem}

Kazakhstan has large and virtually untapped resources of coalbed methane, which, according to various estimations, are about from 2 to 8 trillion cubic meters. These resources include Karaganda (2-4.3 trillion $\left.\mathrm{m}^{3}\right)$ Ekibastuzsky (70 billion $\mathrm{m}^{3}$ ), Tengiz-Korzhunkolsky (45 billion $\mathrm{m}^{3}$ ) basins, Samarskoe and Zavyalovskoe deposits, etc (Daukeev et al., 2002). Such a resource base allows to predict the possibility of development of new fuel and energy, using methane chemical industries in the country.

CBM for Kazakhstan is a new direction in environmental management, therefore it is important to determine all possible anthropogenic impacts on the environment at every stage of the work carried out on site. Mining of coal bed methane permits preliminary degassing of coal seams and thus prevents the release of methane into the atmosphere - a greenhouse gas (GHG) as production of each ton of coal is accompanied by release of 5 to $30 \mathrm{~m}^{3}$ of coalbed methane (Kort et al., 2008). The region of Karaganda CBM production can also receive an additional marketable products - the cleanest fossil fuel, the use of which is accompanied by a significant reduction in air pollution, compared with fuel oil and coal.

\subsection{Hypothesis}

The organization of feasible production of gas-bearing coal basins in Karaganda and other coal basins depends on their appropriate geological characteristics and conditions. This production will allow to improve economic, social and environmental conditions of Central Kazakhstan.

\section{Method}

The research methodology is based on practical and factual material of the LLP "Zhumys-Strojservis", JSC "ArsellorMittal Temirtau" (the main operators in the Karaganda basin), universities (Moscow State Mining University, Novosibirsk State Technical University), research centers (Karaganda State Technical University, LLP "Azimuth Geology"), government authorities, leading international experts and experience of developed countries. Confirmation / refutation of the hypothesis as well as coverage of main issues will be conducted through the review and analysis of the fundamental and applied research in the field of extraction of methane from coal basins.

\subsection{Subsections of the Study}

In order to conduct a comprehensive study of the stated problem the following subsections have been determined:

- Geological features of Karaganda basin;

- Environmental aspects of methane production;

- Methane safety;

- Feasibility study.

Furthermore, these subsections are followed by correspondent results carried out by correlation of geological and geophysical materials of LLP "Zhumys-Strojservis» (Temco Energy Group) and mathematical modeling, determination of environmental benefits from a decrease of GHG emissions from coal mining and estimation of profit growth due to enhanced recovery of methane.

\subsection{Geological Features of Karaganda Basin}

The results of exploration of coal deposits, including the study on coalbed gas content, are the initial information for assessing the resource's base. The main principle of assessing and selecting perspective areas for methane production is keeping its technological, economical and environmental feasibility. It is important to take into account the peculiarities of geodynamics of carboniferous geological structures and arrays (Anderson et al., 2003), which are the predetermining factor in the regional development of not only the natural fractures and permeability of coalbed, but characterize the possibility to use technogenic ways to improve the reservoir permeability, intensification (activation) of gas recovery.

Karaganda coal basin is an asymmetrical rather large complicated syncline, elongated in the latitudinal direction. The hydrogeological conditions of the target formations in the Karaganda basin are relatively favorable. The Karaganda coal basin is one of the gassy (with high gas content). The vast number of mines are over-categorical . 
The geological structure of the basin consists of Paleozoic, Mesozoic and Cenozoic formations. Karaganda basin belongs to the type bi-systemic: coal-bearing is associated with Carboniferous and Jurassic deposits. Jurassic coals - mesokaites and being developed in an open way. Carboniferous coals represent a significant industrial interest. Carboniferous coal-bearing deposits include four coal-bearing formations: ashlyarikskaya, karagandinskaya, dolinskaya and tentekskaya (Azizov \& Vlasov, 1997).

Tectonically the Karaganda basin is confined to Karaganda synclinorium latitudinal distribution, being located in the middle of it. From the south the basin is limited by Zhalairskyi thrust, northern board - sedimentary and volcanic rocks of the Devonian, in the west - a large Tentekskaya fault with a displacement amplitude of $4-5 \mathrm{~km}$. Eastern boundary is considered to be the part where the area of carbon development is narrowed (Dumler et al., 1996). Two transverse uplifts (Alabayskaya I anticline and Maykudukskoe lifting) are dividing the basin into three major troughs (from west to east): Churubay-Nurynskaya, Karagandinskaya and Verhnesokurskaya. The Churubay-Nurynskaya syncline (trough) is a complex asymmetrical fold, elongated in the meridional direction. It holds the full section of coal-bearing strata. The wings of syncline are composed by lower productive suites Ashlyarikskaya and Karagandinskaya. Churubay-Nurynskaya syncline is splited by a large Churubay-Nura thrust into two parts. The western part corresponds to Tentekskaya coal district, and east - Churubay-Nura (Golitsyn et al., 1973). Here the disjunctive dislocation is being developed intensively, while the prevalence of disorders of mainly latitudinal upthrow character is being observed. Many researchers were paying a lot of attention to Karaganda coal-bearing and over-carboniferous section, but the concept of its stratigraphy was founded by Kushev G.L., Semenov Z.P., Simorinov A.M. (Koubaichuk, 2004).

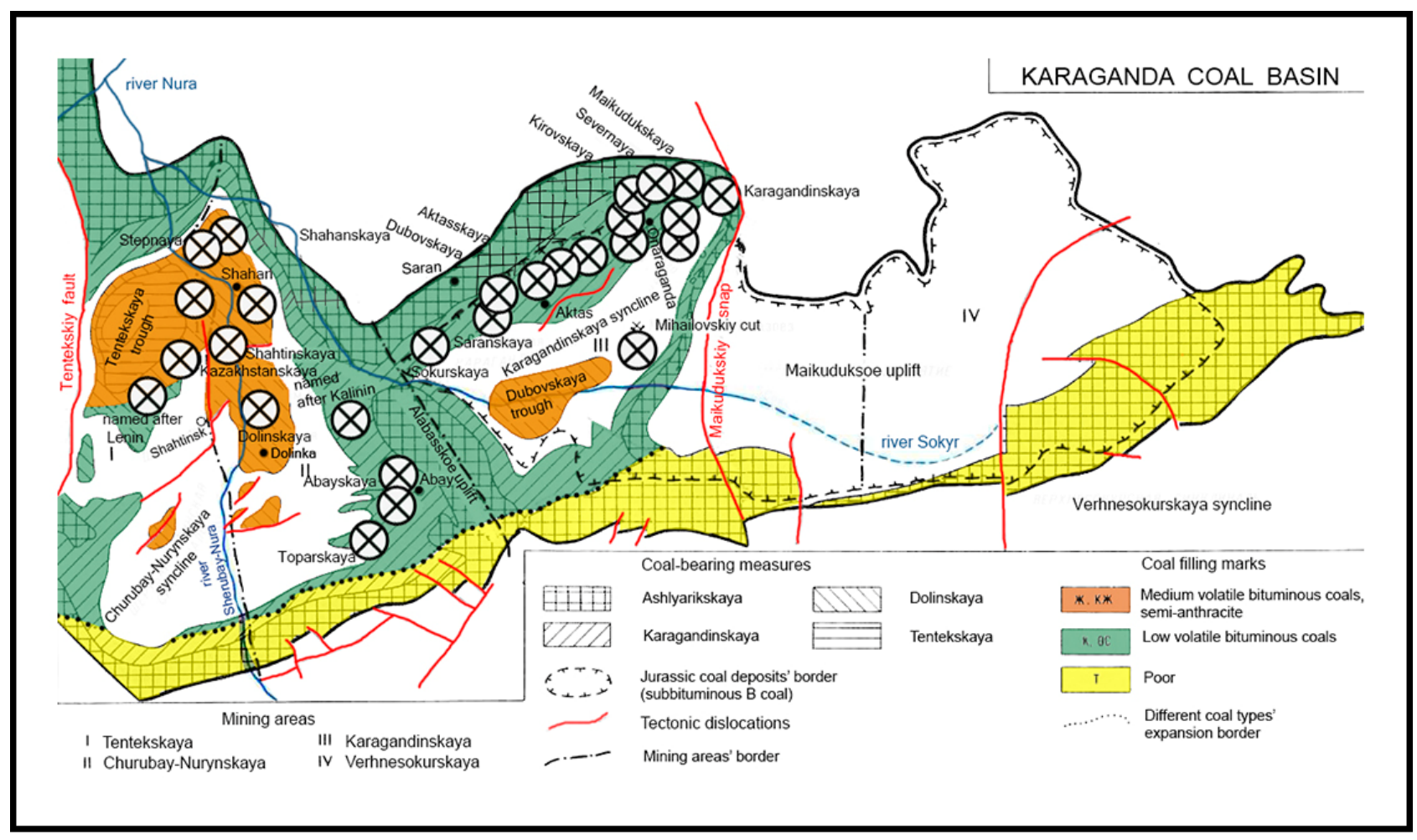

Figure 1. Geological map of Karaganda coal basin (Kler, 1973) (Note 1)

The sectional view covers horizons from the upper half of the Lower Visé to Permian and almost entirely composed of terrigenous clastic rocks with rare interbedded limestones and coal seams in the lower suites (Kler, 1973). The carboniferous of the basin increases along with the circuit and deepening trough as the surrounding ancient landscape was covered with sea essentially, and the climate was warm and humid. After a general regression of the sea in the Moscovian subdivision of the Middle Carboniferous redbeds appeared, coal accumulation was being phased out so that the upper layers of the Carboniferous and Permian do not contain coals. The terrigenous incision is represented by local units and begins with carbonless akkudukskaya suite, including along with the normal detritus also volcanogenic: tuff-sandstones, tuff, tuffites. These deposits are particularly enriched in east direction during Lower Visé and towards limits of Aschisuyskaya syncline. The 
carboniferous incision located above is being divided into two parts: the lower horizons include Middle and Upper Visé, Namurian stage of the Carboniferous system; upper horizons belongs entirely to the upper Paleozoic (Dumler et al., 1996).

The degree of the coal metamorphism increases with stratigraphic depth starting from gas coals of tentekskaya suite and ending with coke and depleting coals of ashlyarikskaya suite. In addition, the metamorphism of coal increases in a southerly direction with the increasing power of the coal-bearing strata, as well as in drop in coal seams. This metamorphism causes a variety of coals from the gaseous to anthracite, inclusive in the south of the basin. The coals are of following types: vitrinite $(60-80 \%)$, with average ash content (10-25\%) in dolinskaya and karagandinskaya suites, with high ash content (20-35\%) in ashlyarikskaya and tentekskaya suites (Adilov et al., 1999, pp. 288-292). The difference in the metamorphism of coal affects the methane distribution according to forms of their existence (Table 1).

Table 1. Distribution of methane according to forms of its existence in the coals of the Karaganda coal basin, middle stages of metamorphism at depths of over $800 \mathrm{~m}$ (Saginov \& Li, 2006)

\begin{tabular}{lcc}
\hline \multicolumn{1}{c}{ Localization of methane in coal } & Form of methane existence & $\begin{array}{c}\text { Quantity of } \\
\text { methane, \% }\end{array}$ \\
\hline $\begin{array}{l}\text { Within the macropores of microcracks and } \\
\text { other defects in the continuity of coal under } \\
\text { natural conditions }\end{array}$ & Unobstructed & $2-12$ \\
$\begin{array}{l}\text { On the surfaces of coal of natural pores and } \\
\text { defects of continuity, interblock gaps } \\
\text { (including volumetric filling of transition }\end{array}$ & Absorbed & $8-16$ \\
pores and macroscopic defects) & & \\
$\begin{array}{l}\text { In the intermolecular space of the coal } \\
\text { substance }\end{array}$ & Solid methane solution & $70-85$ \\
$\begin{array}{l}\text { In the defects of aromatic layers of crystals } \\
\text { Inside clater like structures }\end{array}$ & $\begin{array}{c}\text { Chemically adsorbed methane } \\
\text { Interstitial solid solution }\end{array}$ & $1-2$ \\
\hline
\end{tabular}

\subsection{Environmental Aspects of Methane Production}

Ecological problems of production, processing and use of coal are relevant for modern Kazakhstan. Each year, mines of the Karaganda coal basin produce 10.8 million tons of coal with gas content of $16-57 \mathrm{~m}^{3}$ per ton of coal, with the captured 277 million $\mathrm{m}^{3}$ of methane (out of which 35 million $\mathrm{m}^{3}$ by degassing and 242 million $\mathrm{m}^{3}$ by ventilation). At the moment out of the degassed volume only 12 million $\mathrm{m}^{3}$ of methane (4.3\%) is being used, the remaining amount is burned, making a significant contribution to global pollution of the country and the planet as a whole (Ministry of Industry and New Technologies of RoK, 2009). The crisis environmental situation in the coal-mining regions is determined along with the air pollution and water pollution associated with the destruction of natural landscapes (soil and vegetation). With such a large scale of destruction of natural landscapes coal mining areas meet the criteria for their inclusion in the zones of "ecological disaster." The degree of impact on the environment of these technogenic landscapes is so significant that it can not be assessed only on the damage caused to agriculture or forestry. Drastic changes in the nature of biological and soil-geochemical processes caused by mining operations, accompanied by a trail of negative environmental impacts, covering all the Karaganda region and surrounding areas due to the transport of pollutants from disturbed land by river runoff and wind. Taking into account current level of coal production and concentration of coal enterprises, their impact on the environment (on the surface and subsoil reserves) determined as overly large. The impact of coal transportation over long distances, burning, emissions are becoming large-scale processes occurring and spreading far beyond the coal-mining regions. This impact is followed by violation of the surface without further land reclamation, the location of storage sites of solid and liquid waste, the loss of hundreds of water sources, small rivers, disruption of the hydrological and hydrochemical groundwater regimes (Vidic et al., 2013) and causes serious consequences for the nature, life and health of population.

The development of CBM resources is accompanied by impact on the environment. Drilling, hydraulic fracturing of the coal seam, drainage wells, as well as the stage of methane production, are associated with specific technogenic impact. Methane is released as a "fugitive" emission during the drilling and production of both unconventional and conventional wells, and as part of the processing, transportation and storage of the gas (Cathles, 2012, Howarth et al., 2011). In terms of environmental pollution technology of methane production 
from coal seams can be divided into the following main steps:

- drilling of wells;

- intensification (fracturing) of coal seam and creation of reservoirs of increased drainage capacity (King \& King, 2013);

- drainage of the coal seam;

- extraction of methane.

In the areas of CBM production the soil has a significant technological impact due to the deposition of pollutants from emissions of coal mining (open pit), processing plant, boiler, and other objects. The impact on vegetative cover and animal world is connected with a number of direct and indirect factors, including:

- mechanical damage;

- fires;

- pollution and littering;

- changes in the physical properties of soils;

- changes in groundwater levels, water balance and flow conditions (waterlogging or flooding, dehydration) (Arthur et al., 2008);

- noise and vibration effects in the operational work (drilling);

- emergencies.

The closure of coal enterprises can lead to even more aggravate the ecological situation in the region. International practice on the examples of mine closures UK shows that environmental and anthropogenic impact is seen far beyond the mining leases of coal enterprises, and can be assigned in time for many years from the date of liquidation of the mining enterprise (Vengosh et al., 2014).. This phenomenon is primarily due to groundwater transfer of contaminants to the zone of the underground potable water intakes, due to extrusion and transfer of toxic gases, due to flooding large areas and formation of swamps within the boundaries of cities and towns. In this regard, it is necessary to establish an effective system of production and use of coal bed methane, as a way of reducing the environmental impact of the coal industry. Despite the fact that in the Republic of Kazakhstan coal bed methane is not defined as an independent mineral resource, it is environmentally friendly, efficient energy and chemical raw material. Coalbed methane can be extracted as a standalone product and as a byproduct produced during mine degasification before mining coal.

It should be noted that during extraction of methane from coal seams the ecological efficiency is mainly determined by the difference in the specific allocation of greenhouse gases (GHG) between CBM and replaceable raw material. Preliminary extraction of methane within the mining leases of mines drastically cuts down the GHG emissions even in the absence of methane utilization and its flaring (Moore et al., 2014). In connection with this environmental evaluation was carried out with the following assumptions:

1. Preliminary extraction of methane from coal seams at various technologies is carried out within the mining lease of mines.

2. As an alternative adopted zero option - the rejection of preliminary extraction of methane from unloaded coal seams.

\subsection{Methane Safety}

The main emphasis in solving problems of the methane safety is to improve the control systems of methane in the atmosphere of mines and, to a lesser extent, control of schemes of ventilation and degasification. The main sources of ignition of methane-air mixtures are explosive works; electrical equipment and apparatus, frictional sparks, even smoking and a number of other reasons, which respectively correspond to $46 \%, 22 \%, 12.6 \%$ and $10 \%$ of all emergency cases (Sayers et al., 2004). It should be noted that in these estimations such an important factor as gas-dynamic phenomena is not taken into account. The solution of this phenomena has a very limited range of possibilities: preparation of protective layers, preliminary degassing and field preparation. Under these conditions, a radical determination of the problem is possible only through an integrated approach, covering both the technical and technological solutions increase of methane production, and organizational solutions.

The question of commercial production of coalbed methane in the Karaganda basin is quite difficult. The coal seam itself is a sophisticated low-permeable fractured media block with a huge anisotropy and inhomogeneity of the properties. It should noted that $80-90 \%$ or more $(98 \%)$ of coalbed methane is in adsorbed state 
(Akhmetbekov, 1994). If it is taken in a free state, then the process of migration to the well is very durable, requires significant changes in the state and properties of coal-gas-saturated concrete. A substantial portion of the pore space coalbed is represented by pore size of from 1 to $10 \mathrm{~nm}$ where the capillary condensation and diffusion of gas are present, by pore size of from 10 to $100 \mathrm{~nm}$ where there is a slow laminar gas filtration, etc. (Palmer et al., 2005). All the following can be characterized as a transportation processes of methane, requiring considerable time. In the macropores (Poiseuille pores) the mass transfer process is slightly faster where there is an intense laminar filtering (Vasuchkin, 1986). In addition, only under conditions of visible pores and cracks in the case laminar and turbulent mixed filtering process is occurring which may be provided by more or less acceptable yields of wells. The mechanism of extraction of methane from coal seams with low permeability is very specific and has nothing to do with the mechanism of gas flow in the operation of clean gas fields (Stevens \& Hadiyanto, 2004, Tsang et al., 2008). All this determines the need for the widest possible use of the experience of scientists and experts in the extraction of coal bed methane in the process of degassing of coal seams from the surface through wells. For the period over 35 years more than 20 mining fields in the Karaganda basin were prepared for a safe and efficient development, using this technology (ArcelorMittal Coal Mines, 2013). The problem of CBM production is a very important and urgent task for the coal and energy industries of Kazakhstan. From our point of view, at the intersection of their interests, balanced and informed decision of the problem of extracting methane from coal seams and of ensuring follow-up of methane coal is underlined. This defines the feasibility of carrying out first pilot projects on mine fields in areas of coal fields, where at least in the distant, but the foreseeable future mining activities will be carried out, which in any case have to ensure the economic viability of the works on extraction (mining) of methane by increased pressures on production faces, by increased rate of development workings, by rational utilizing of methane recovered, by environmental factors.

\subsection{Feasibility Study}

Primarily in terms of post-soviet industrial economy CBM in subsurface mining was considered as a source of potential explosion hazard (emissions, piper and intensive gassing). Today, R\&D achievements allow us to shift to the new geotechnological methods of early methane recovery from coalbed layers (methods of directed hydro-dissection of layers) and subsequent use of gas as an energy resource (Christiaansen et al., 2007). In the short term use of CBM, not only as an energy source (in liquid form for disposal), but also as a valuable raw material and product for chemical industry (food grade acetic acid, acetylene, product synthesis gas, etc.) is genuinely realistic and obvious. On this basis, it is reasonable to avoid sectoral approach in estimation of coalbed reserves and radical reorientation of their values.

The feasibility of organizing exploration and production of CBM fields in the Karaganda basin is determined by the following factors:

- the presence of large deposits of methane in coal basins of Kazakhstan;

- the availability of modern advanced technologies for commercial production of methane from coal seams that are widely used in recent years abroad;

- the presence in Kazakhstan scientific and technical potential, the ability to coordinate and carry out scientific research on the topic.

According to preliminary estimates (Ministry of Industry and New Technologies of RoK, 2009), in the coal seams of the Karaganda basin there are about 4.3 trillion $\mathrm{m}^{3}$ of methane, which is a valuable, environmentally friendly fuel with the caloric content equivalent to 2 billion tons of coal. The following question naturally arises: how natural gas deposits of Karaganda basin can be used cost-effectively within the energy sector of the country.

In conducted study the global experience based on availability of technologies for the efficient extraction of methane from coal seams is stated as objective prerequisite for the organization of commercial production of methane in the Karaganda basin. This experience allows to ensure cost-effective production of coal bed methane as an independent mineral resource. 
Table 2. Comparative analysis of the geological parameters of coal deposits worldwide (Puchkov et al., 2003, Roberts et al., 2006).

\begin{tabular}{|c|c|c|c|c|c|c|}
\hline $\begin{array}{r}\text { Geological } \\
\text { parameters / } \\
\text { basin, country }\end{array}$ & $\begin{array}{r}\text { Karaganda } \\
\text { basin / } \\
\text { Kazakhstan } \\
\text { (to a depth of } \\
1800 \mathrm{~m} \text { ) }\end{array}$ & $\begin{array}{r}\text { Black Warrior } \\
/ \text { USA }\end{array}$ & $\begin{array}{r}\text { Number of } \\
\text { basins / Great } \\
\text { Britain }\end{array}$ & $\begin{array}{r}\text { Number of } \\
\text { basins } / \\
\text { France }\end{array}$ & $\begin{array}{r}\text { Number of } \\
\text { basins / } \\
\text { Germany }\end{array}$ & $\begin{array}{r}\text { Number of } \\
\text { basins / } \\
\text { Poland }\end{array}$ \\
\hline $\begin{array}{l}\text { Methane } \\
\text { resources, } \\
\text { [billion } \mathrm{m}^{3} \text { ] }\end{array}$ & 850 & 566 & $100-2000$ & 510 & 2800 & $800-1500$ \\
\hline $\begin{array}{r}\text { Geological } \\
\text { age }\end{array}$ & $\begin{array}{l}\text { Lower-Upper } \\
\text { Carboniferous }\end{array}$ & $\begin{array}{l}\text { Lower-Upper } \\
\text { Carboniferous }\end{array}$ & $\begin{array}{r}\text { Carboniferou } \\
\mathrm{S}\end{array}$ & $\begin{array}{r}\text { Lower } \\
\text { Carbonifero } \\
\text { us }\end{array}$ & $\begin{array}{r}\text { Carbonifero } \\
\text { us }\end{array}$ & $\begin{array}{r}\text { Carboniferou } \\
\mathrm{S}\end{array}$ \\
\hline $\begin{array}{r}\text { Total capacity } \\
\text { of the coal } \\
\text { seams, } \\
\text { maximum } \\
\text { thickness of } \\
\text { layers, }[\mathrm{m}]\end{array}$ & 8.8 & 1.5 & $1.5-2$ & $1.5-5$ & $1.5-2$ & $20-70$ \\
\hline $\begin{array}{r}\text { Structural } \\
\text { forms }\end{array}$ & $\begin{array}{r}\text { Favorable, } \\
\text { faults, } \\
\text { anticlinal } \\
\text { folds. } \\
\text { Depth up to } \\
1800 \mathrm{~m} .\end{array}$ & $\begin{array}{r}\text { Favorable, } \\
\text { divisional } \\
\text { faults, } \\
\text { anticlines. } \\
\text { Depth up to } \\
1500 \mathrm{~m}\end{array}$ & $\begin{array}{r}\text { Favorable, } \\
\text { faults, traps. } \\
\text { Depth up to } \\
2000 \mathrm{~m}\end{array}$ & $\begin{array}{r}\text { Favorable, } \\
\text { faults, traps. } \\
\text { Depth up to } \\
2000 \mathrm{~m}\end{array}$ & $\begin{array}{r}\text { Favorable, } \\
\text { faults, traps. } \\
\text { Depth up to } \\
2000 \mathrm{~m}\end{array}$ & $\begin{array}{r}\text { Favorable, } \\
\text { faults, traps. } \\
\text { Depth up to } \\
2000 \mathrm{~m}\end{array}$ \\
\hline $\begin{array}{r}\text { Metamorphis } \\
\mathrm{m} \text { (grade) of } \\
\text { coal }\end{array}$ & $\begin{array}{r}\text { High volatile } \\
\text { bituminous } \\
\text { coals - } \\
\text { Semi-anthraci } \\
\text { te }\end{array}$ & $\begin{array}{r}\text { Medium } \\
\text { volatile } \\
\text { bituminous } \\
\text { coals - } \\
\text { Semi-anthraci } \\
\text { te }\end{array}$ & $\begin{array}{r}\text { Subbitumino } \\
\text { us A coal - } \\
\text { Lignite A and } \\
\text { B }\end{array}$ & $\begin{array}{r}\text { High } \\
\text { volatile } \\
\text { bituminous } \\
\text { coals - } \\
\text { Medium } \\
\text { volatile } \\
\text { bituminous } \\
\text { coals }\end{array}$ & $\begin{array}{r}\text { High } \\
\text { volatile } \\
\text { bituminous } \\
\text { coals - } \\
\text { Semi- } \\
\text { anthracite }\end{array}$ & $\begin{array}{r}\text { Subbitumino } \\
\text { us A coal - } \\
\text { High volatile } \\
\text { bituminous } \\
\text { coals }\end{array}$ \\
\hline $\begin{array}{r}\text { The gas } \\
\text { content, } \\
{\left[\mathrm{m}^{3} / \text { ton }\right], \text { the }} \\
\text { presence of } \\
\text { gas shafts }\end{array}$ & $\begin{array}{r}0-33 \\
\text { (average-21), } \\
\text { gas shafts }\end{array}$ & $\begin{array}{r}0-17 \\
\text { (average }-11 \text { ), } \\
\text { gas shafts }\end{array}$ & $\begin{array}{r}0-17 \\
\text { (average } \\
-11 \text { ), } \\
\text { gas shafts }\end{array}$ & $\begin{array}{r}\text { Average-7.3, } \\
\text { gas shafts }\end{array}$ & $\begin{array}{r}0-18 \\
\text { (average-6.3 } \\
\text { ), } \\
\text { gas shafts }\end{array}$ & $\begin{array}{r}1-7, \\
\text { gas shafts }\end{array}$ \\
\hline $\begin{array}{r}\text { Hydrodynami } \\
\text { cs }\end{array}$ & $\begin{array}{r}\text { Salted water } \\
\text { up to } 10 \\
\mathrm{~g} / \mathrm{dm}^{3} \\
\text { pressurized }\end{array}$ & Salted water & $\begin{array}{r}\text { Salted water } \\
\text { up to } 10 \\
\mathrm{~g} / \mathrm{dm}^{3}, \\
\text { possible } \\
\text { mineralizatio } \\
\mathrm{n} \text { of cracks }\end{array}$ & $\begin{array}{r}\text { No } \\
\text { Information }\end{array}$ & $\begin{array}{r}\text { No } \\
\text { Information }\end{array}$ & $\begin{array}{r}\text { Formational } \\
\text { water, highly } \\
\text { salted }\end{array}$ \\
\hline
\end{tabular}

As it can be seen from Table 2, the geological parameters Black Warrior Basin, one of the largest basins in the United States, is significantly inferior to the parameters of the Karaganda coal basin. The gas content in the Karaganda basin is almost twice more than the mean gas content in the other the world's largest deposits.

\section{Results}

\subsection{Gas Content Evaluation Based Geological Features of Karaganda Basin}

The table 1 shows that the vast majority (about $80 \%$ ) of methane of Karaganda coal basin at a depth of over 800 $\mathrm{m}$ is in a state of a solid methane solution. The following conclusion can be drawn: efficient extraction of 
methane of Karaganda coal basin requires energy impact on the coal seams that will stimulate the decay of a solid methane solution and the corresponding gas extraction.

The methane, released from the undermined strata (neighboring), is able to move over cross macrocracks, cavities of bundle (Weber) (Glasby, 2006), cross-border array of disturbed areas through large distances (from the zone of clearing works) and can be capped remotely up to $1000-1200 \mathrm{~m}$ in the fall or the strike of the formation.

Therefore, all-out space of producing or exhausted column should be considered as technogenic gas collector, not a patch goaf of working face to the seal area caving. During the non-unified technology of production of layers, the whole area of producing or exhausted columns becomes the gas manifold. Pinching layers within the array, the line of their fracture, which are inclined to the horizontal at an angle of $55-80^{\circ}$, are considered as boundaries of gas collector.

Based on correlation of materials of LLP "Zhumys-Strojservis» (Temco Energy Group) for Schlumberger Data Processing and Consulting Services, Figure 2 shows the dependence of the gas content left in the goaf coal packs on their thickness for the conditions of formation of the recess $d_{6}$ on mine "Shakhtynskaya" (curve $1-L_{1}$ ) and the formation of the recess $\mathrm{k}_{10}$ on mine "Abai" (curve $2-\mathrm{L}_{2}$ ). Figure 2 illustrates that with the decrease of removable thickness of the reservoir $\mathrm{d}_{6}$ from 4.0 to $2.5 \mathrm{~m}$ the gas volume of left coal stacks increases from 0 to $10 \mathrm{~m}^{3} / \mathrm{t}$. On mine "Abaiskaya" along with $\mathrm{k}_{10}$ layer during the decline of removable thickness from 5.0 to $2.5 \mathrm{~m}$ from left packs the gas production increases from 2.6 to $9.0 \mathrm{~m}^{3} / \mathrm{t}$ of coal mining.

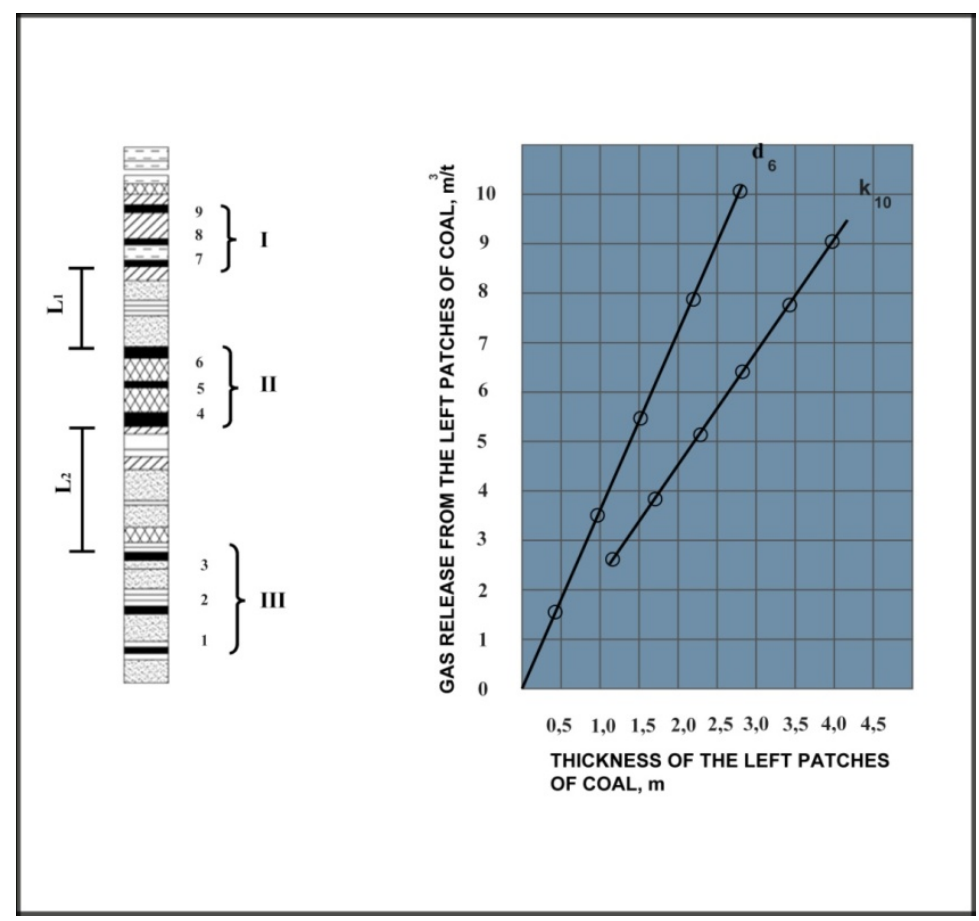

Figure 2.The dependence of gas release intensity from abandoned coal packs on their thickness.

Table 3 shows the distribution of methane extracted by means of drainage and ventilation of the main layers of the Karaganda (Kwon \& Aliyev, 2003). 
Table 3. Distribution of methane during degassing and ventilation

\begin{tabular}{|c|c|c|c|c|}
\hline Layers & $\begin{array}{c}\text { Relative gas volume } \\
\text { of lava } \mathrm{m}^{3} / \mathrm{t}\end{array}$ & Mines & $\begin{array}{l}\text { Volume of gas in the } \\
\text { goaf, } \mathrm{m}^{3} / \mathrm{t}\end{array}$ & $\begin{array}{l}\text { The total } \\
\text { volume of gas } \\
\text { per } 1 \text { ton of } \\
\text { coal m }{ }^{3} / \mathrm{t}\end{array}$ \\
\hline $\mathrm{k}_{12}$ & 31 & 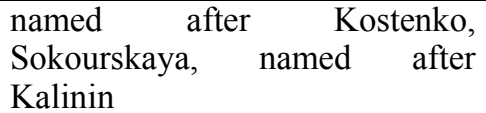 & 8 & 42 \\
\hline $\mathrm{k}_{10}$ & 22 & $\begin{array}{l}\text { Sokourskaya, named after } \\
\text { Kalinin, Kouzembayev }\end{array}$ & 7 & 32 \\
\hline $\mathrm{k}_{7}$ & 32 & $\begin{array}{l}\text { named after Kostenko, } \\
\text { Sokourskaya }\end{array}$ & 10 & 45 \\
\hline $\mathrm{d}_{6}$ & 27 & $\begin{array}{l}\text { named after Lenin, } \\
\text { Kazakhstanskaya, Shahtinskaya }\end{array}$ & 7 & 37 \\
\hline $\mathrm{d}_{10}$ & 22 & $\begin{array}{l}\text { named after Lenin, } \\
\text { Kazakhstanskaya }\end{array}$ & 6 & 31 \\
\hline
\end{tabular}

\subsection{Environmental Benefits of Methane Extraction during the Coal Mining}

In view of stated, the purpose of a current subsection is to define ecological and economic implications of this method (preliminary degassing) in its relation to option of no usage of this method (zero option). Currently, coal deposits around the world are considered from the point of extraction of solid fuel and gas, the use of which in energy generation leads to emissions of greenhouse gases: carbon monoxide and methane. Taking into account the steady growth of world coal production, the share of emissions of methane from coal deposits will continue to increase, polluting the atmosphere with noxious gases. It is, therefore, necessary to create a base for a successful recovery and industrial use of methane, for example, as unconventional source of energy generation. The expansion and development of the technology of hydraulic partition of coal seams can become such a base.

However, the widespread implementation of preliminary degassing is constrained by low flow rates of methane from the wells, which is due to insufficient knowledge of the physical processes that occur during the extraction of gases. Therefore, in order to create a technology aimed at intensifying the extraction of methane, it is necessary to define the laws of gas-dynamic processes occurring in the coal seam. Operation of any enterprise, in this case - a mine, as if option of no usage of preliminary degassing (zero option) and its application (basic version), has a negative impact on the environment. Preliminary extraction of methane does not envisage any changes in the technology of coal mining. Under these conditions, in the case of the zero option, the change of the environmental impact in the long term is determined by the amount methane emissions from flaring. The impact on the air quality is manifested by:

1. Allocation of gas emissions from methane flaring recovered during the entire period of wells' operation.

2. Allocation of harmful gases emitted during the operation of auxiliary equipment (usually diesel driven) for the processing of coal beds (depending on the number of wells and production technology).

The total estimated consumption of diesel fuel used in an implementation of technology of preliminary methane recovery is about 26 tons per well. The harmful emissions from the equipment used in the construction and well treatment are identified on the basis of calculated fuel consumption and associated emissions from units and listed in Table 4.

Table 4. Emissions from well construction and well operation (ArcelorMittal Coal Mines, 2013)

\begin{tabular}{|c|c|c|c|c|}
\hline \multirow{3}{*}{ 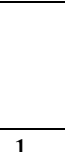 } & \multirow{2}{*}{ Designation harmful substances } & \multirow{2}{*}{$\begin{array}{c}\text { Specific emissions of } \\
\text { harmful substances per } 1 \\
\mathrm{~g} \text { of fuel, }[\mathrm{g} / \mathrm{g}]\end{array}$} & \multicolumn{2}{|c|}{ Emissions of harmful substances } \\
\hline & & & $\begin{array}{l}\text { Maximum, } \\
{[\mathrm{g} / \mathrm{sec}]}\end{array}$ & Gross, [tons] \\
\hline & Carbon monoxide & 0,03 & 3 & 0,8 \\
\hline 2. & $\begin{array}{l}\text { Oxides of nitrogen (calculated as } \\
\mathrm{NO}_{2} \text { ) }\end{array}$ & 0,04 & 4 & 1,1 \\
\hline 3. & Sulfur dioxide & 0,02 & 2 & 0,5 \\
\hline 4. & Hydrocarbons & 0,03 & 3 & 0,8 \\
\hline 5. & Soot & 0,0155 & 1,55 & 0,4 \\
\hline & TOTAL: & & 13,55 & 3,6 \\
\hline
\end{tabular}


The maximum emission of pollutants from the combustion of diesel fuel occurs in the process of hydro-dissection of the coal seam (6 simultaneous operations of pump units) while diesel consumption is 128 $\mathrm{kg} / \mathrm{h}$. Duration of maximum emission in the processing of a single well is about 45 hours. Estimated gross emissions from operating equipment in the processing of one well is 3.6 tons. Indicators on emissions of air pollutants by source of emissions is provided in Table 5 .

Table 5. Emissions by the source

\begin{tabular}{llccc}
\hline Designation harmful substances & \multicolumn{3}{c}{$\begin{array}{c}\text { Inorganic sources of emissions } \\
\text { Sumping units } \\
\text { Sand-mixing equipment } \\
(\text { YCח-50) }\end{array}$} & $\begin{array}{c}\text { Disposing flares } \\
\text { items }\end{array}$ \\
\hline 1. & Carbon monoxide & $0,12 / 0,33$ & $2,28 / 3$ & \\
2. & Oxides of nitrogen (calculated as & $0,16 / 0,44$ & $3,04 / 4$ & $18,84 / 0,6$ \\
& $\mathrm{NO}_{2}$ ) & $0,08 / 0,22$ & $1,5 / 0,05$ \\
3. & Sulfur dioxide & $0,12 / 0,33$ & $2,28 / 3$ & - \\
4. & Hydrocarbons & $0,06 / 0,17$ & $1,18 / 1,55$ & - \\
5. & Soot TOTAL: & $0,54 / 1,49$ & $10,3 / 13,55$ & $20,34 / 0,65$ \\
\hline
\end{tabular}

The estimated value of total emissions of pollutants in the atmosphere is 31.2 tons. Moreover, as a result of methane flaring extracted from the wells with a flow rate of $1 \mathrm{~m}^{3} / \mathrm{min} 1,029$ tons of $\mathrm{CO}_{2}$ is being produced. In order to conduct comprehensive estimation of the value of total emissions it should be noted that the extraction of mine with gas content of $50 \mathrm{~m}^{3} / \mathrm{t}$ and production rate of one million tons of coal per year the emission of methane itself is equivalent to almost 700 thousand tons of $\mathrm{CO}_{2}$ (ArcelorMittal Coal Mines, 2013). Depending on the mining geological conditions with the aim to ensure the production of one million tons of from 3 to 8 preliminary degassing wells are required. Thus, the calculations show that the share of emissions from the use of technology advance methane recovery (preliminary degassing) in the share of total air pollution is negligible and does not exceed 1\%. In accordance with the Kyoto Protocol if the mechanism of emissions trading of GHG emissions and joint implementation (JI) projects are applied, it is necessary to take into account the value of reduced GHG emissions.

When methane is used to produce heat or electricity additional environmental impact is determined by the difference of the of specific $\mathrm{CO}_{2}$ emissions per 1 unit of power. So during methane usage in the boiler room (in the form of transferring from coal to gas), $\mathrm{CO}_{2}$ emissions from the same heat output will be reduced to 1.74 times, i.e. in transferring for methane usage option of one boiler (ДКВР- 10/13) absolute carbon dioxide emissions are reduced by almost 15 tons per year. With the cost of one ton of carbon equivalent from 10 to 15 USD the economic effect even in the case of flaring will be about 3.2 million USD, which exceeds the cost of establishment of preliminary degassing option. However, taking into account the time factor the economic efficiency is still more than $75 \%$. Thus, the use of technology advance methane recovery will reduce the emission of GHG into the atmosphere. Even in case the cost of one ton of carbon equivalent will not be less than 7 USD (the economic benefit of reducing GHG emissions will exceed the cost of preliminary degassing application.

\subsection{Premise of Ensuring Methane Safety}

The approaches to the development of resource-efficient clean technology of development for coal deposits with high gas content are being tested for the last ten years at the mines "named after Lenin," "Kazakhstan" and "Shakhtinskaya". In following decade, a large range of technological solutions for the extraction of methane from unloaded from rock pressure coal seams has been tested. On the mine "Kazakhstan" a complex of 25 gas wells with a maximum flow rate of methane per well up to $1.5 \mathrm{~m}^{3} / \mathrm{min}$ (methane is extracted only from one of the working layers) has been established presenting a concentration of methane in the extracted mixture of $96-98 \%$ (Ministry of Industry and New Technologies of RoK, 2009). Currently, all of these wells are caring flare methane recovery (methane flaring), which reduces emissions of GHG into the atmosphere by 30 thousand tons per year of carbon equivalent. At a cost of 15 USD for 1 ton of carbon equivalent economic benefit from the sale of quotas under the Kyoto Protocol within JI projects could reach 450 thousand USD.

The gas production should be applied in advance, for 5-10 years before the start of mining operations. At the 
same, the layout and parameters wells' location should be determined taking into account the plan for future mining operations for coal extraction (Davies et al., 2014). This planning will allow during coal production to reduce the risk of methane explosions due to significant degassing of working layers. The mining operations during the lifecycle of the mine results in unloading coal rock mass and increasing methane recovery of carbonaceous gas-saturated rocks. At this stage, it is advisable to use complex methods to extract methane, which combine surface wells, previously used for a preliminary degassing, and subterranean wells, joined in a single system (Mavor et al., 2004). In the process of unloading the array yields of wells are increasing tenfold, but the air suction of the mine workings grows as well, causing a reduction in gas concentration, which requires special measures to maintain the conditional parameters of extracted gas mixture (Olsen et al., 2003). With the aim to ensure a steady flow rates of methane (both in terms of volume and concentration), it is necessary to take into account patterns of methane emissions from reservoirs and unloaded spaces, as well as the impact of air filtration processes in the undermined array on the parameters of extracted gas mixture.

Therefore, changes in patterns of desorption and methane drainage in various stages of development of coal deposits indicate that the requirements for the gas production technology in the process of coal mining are also changing. Thus, three stages of methane extraction corresponding to fundamentally different types of stress-strain state of the array are being proposed:

- period of design and construction of the mine, corresponding to methane production from unloaded array;

- period of operation (development of mining operations, development of design capacity and attenuation) to the full development of reserves or the closure of the mine for other reasons; this stage corresponds to the conditions of extraction of methane from unloaded array;

- period from the beginning of the isolation of individual areas and the closure of the mine as a whole till complete the gas depletion of undermined strata; this period corresponds to the conditions of the methane extraction from old goaf.

Because all three phases cannot be clearly separated in time, as change in the stress-strain state of the process of coal extraction occurs constantly (from the state of nature to decay full displacement), all three stages can occur simultaneously in the same mine field. Therefore, a multistage technology is the most efficient, involving the use of same wells for methane production at all stages of field development. However, the modes of operation of these wells, as we move from the first stage of field development to the last, will be different.

\subsection{Economic Efficiency}

Some private companies (which perform their works at the exploration stage) are located in Karaganda basin. Manufacture company "Arcelor Mittal" produces methane (taking into consideration all coal mining legal requirements) by removing dissolved gases from liquids at 300-600 meters deep underground level. Due to the lack of proper pipeline infrastructure in this area, the methane gas is released directly to the atmosphere. "Arcelor Mittal" is negatively influenced by low flow rates and by pipeline construction (as it is not cost-efficient). According to the International Energy Agency, the cost of production at such facilities is between 115 to 305 US dollars per $1,000 \mathrm{~m}^{3}$. At the same time in the USA, where, according to JPMorgan investment bank, in 2009 the share of coal bed methane amounted to $7.6 \%$ of the total production of shale gas (56 billion $\mathrm{m}^{3}$ ) (Schlumberger, 2013). Production cost, including transportation cost, has been estimated in the range from 120 to 200 dollars per thousand cubic meters (traditional gas production projects demonstrate lower costs starting from 30 dollars). In assessing the prospects for such projects in Kazakhstan, it is important to focus on these figures. After all, the U.S. production is carried out far away from the consumer.

According to rough evaluations in the Karaganda basin CMB reserves at Saransk site is approximately 68.0 billion $\mathrm{m}^{3}$, at Taldykuduk site -25.0 billion $\mathrm{m}^{3}$. Saransk site covers an area of $97 \mathrm{~km}^{2}$ and Taldykuduk site - 36 $\mathrm{km}^{2}$. Large areas of Saransk and Taldykuduk sites imply the presence of uneven distribution of reservoirs with naturally high methane-bearing (Ministry of Industry and New Technologies of RoK, 2009). Saransk and Taldykuduk areas have the same concentration of CBM recovery (from $15 \mathrm{~m}^{3} / \mathrm{t}$ to $25 \mathrm{~m}^{3} / \mathrm{t}$ ) as in US San Juan basin (Figure 3). Hence, methane reaches the high flow rate of $8-10 \mathrm{~m}^{3} / \mathrm{min}$ in the most favorable areas of San Juan. 


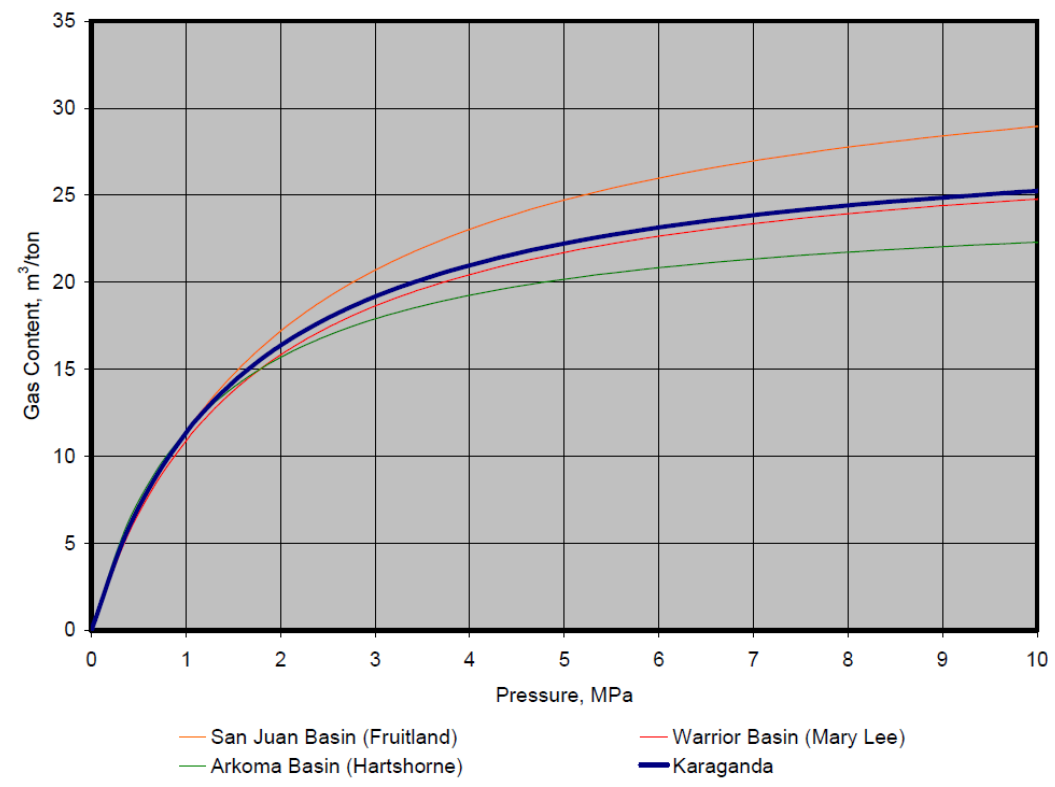

Figure 3. The comparative graph, illustrating the gas capacity in San Juan, Arkoma, Black Warrior and Karaganda coal basins

The Figure 3 proves, that there significant gas reserves in nonbearing and undermined formations. The target formation is distant from locations, where gas reserves are produced, and the limiting value is allocated in close proximity. Importantly, methane is produced from these resources and mostly used for industrial and domestic needs.

\section{Discussion}

In general, the possibility of commercial production of coalbed methane is justified by:

- high gas potential of the Karaganda coal basin;

- existence of both foreign and domestic high-performance and highly profitable technology CBM development;

- presence of scientific and technical capacity, able to carry out and coordinate scientific research on this topic (for example, Karaganda State Technical University, LLP "Azimuth Geology," etc.);

- $\quad$ existing positive experiences in the use of coal-bearing strata (for example, LLP "Zhumys-Strojservis", JSC "ArsellorMittal Temirtau");

- need to ensure environmental and industrial safety in subterranean coal mining.

The stated research hypothesis has confirmed that the involvement of coalbed methane in overall energy balance of Kazakhstan will contribute to the solution a number of problems:

- Social: improvement of safety of mining operations in the coal industry and, as a consequence, reduction of the number of deaths and injuries due to declined risk of mines explosions; creating new job placements in gas fields and thus reducing social tensions in coal-mining areas.

- Economic: creation of a new energy industry in the Republic of Kazakhstan, based on the use of methane; decrease in costs of the subsequent coal production; reduction in costs associated with the liquidation of the consequences of accidents in mines and increase in coal production; decline of purchase cost and transportation cost of natural gas from gas-producing areas.

- Environmental: improvement of ecology in coal mining areas, due to the reduction of emissions from coal mines in atmosphere of Central Kazakhstan.

\section{Conclusion}

The following article aimed to generalize and analyze different aspects of CBM production in Karaganda basin.

On our opinion, the next stages of research address: 
- An assessment of the gas content and reserves estimation in the perspective areas of Karaganda coal basin through the field (sampling) and analytical work. This assessment will become a precondition for the formation of the most appropriate and effective development scheme of coalbed methane production.

- An integration of disciplines (geophysical, geological, petrophysical) and reservoir data (reservoir engineering) to achieve a success in CBM Development Planning for Karaganda coal basin. Comprehensive planning will allow to increase the probability of drilling higher deliverability wells and higher GIP $/ \mathrm{km}^{2}$ wells (Hower et al., 2003).

- In order to fill the gap and update the scientific information (consequence of post-soviet crisis in national R\&D sector) a development of CBM Databases (Mohaghegh et al., 2005), including related information on literature, reservoir characteristics and production.

\section{References}

Adilov, K. N., Akhmetbekov, Sh. U., \& Amanbyev, B. G. (1999). Rationale of parameters for intensification of methane extraction by wells of coalbed formation according to reliability criteria. Modern problems of coalbed methane (pp. 288-292). Moscow: Publishing office of Moscow State Mining University.

Akhmetbekov, Sh. U. (1994). Extraction of methane from coal seams in the conditions of Karaganda basin. Karaganda: Center of Scientific and Technical Information.

Alekseyev, A., Uyanova, E., \& Razumov, O. et al. (2010). Nature of Coalbed Methane (1st ed., Vol. 2, pp. 1-17). Moscow: Energyonline.

Anderson, J., \& Simpson, M. et al. (2003). Producing Natural Gas from Coal. Oilfield Review, $15,8-31$. Retrieved July 13, 2014, from http://www.sbl.com/ /media/Files/resources /oilfield_review/ors03/aut03/p.8_31.pdf

ArcelorMittal Coal Mines. (2013). Pre-feasibility Study for Coal Mine Methane Drainage and Utilization. Karaganda Coal Basin, US EPA: ArcelorMittal Coal Mines. Retrieved June 9, 2014, from http://www.epa.gov/cmop/docs/EPA_CMOP_AM_Kazakhstan_Prefeas.pdf

Arthur, J. D., Langhus, B. G., \& Vonfeldt, C. (2008). Current and Evolving Issues Pertaining to Produced Water and the Ongoing Development of Coal Bed Methane: Proceedings of the 2008 International Coalbed and Shale Gas Symposium (pp. 1-12). Tuscaloosa, Alabama, USA.

Azizov, T. M., \& Vlasov, V. I. (1997). Basins and deposits of coal and shale gas reserves of Kazakhstan. Almaty: Handbook.

Cathles, L. M. (2012). Assessing the greenhouse impact of natural gas. Geochemistry, Geophysics, Geosystems, 13. http://dx.doi.org/10.1029/2012GC004032

Christiaansen, E., Bourgeois, D., MacDonald, C., Longmuir, K., Natras, T., \& McIlreath, I. (2007). Proactive Geosteering with Directional Deep Resistivity and Rotary Steerable Tool in Thin Coalbed Methane (CBM) Reservoirs: Proceedings of the 2008 AADE National Technical Conference and Exhibition (paper AADE-07-NTCE-13, pp. 1-15). Houston, USA.

Daukeev, S. Zh., Uzhkenov, B. S., \& Abdulin, A. A. et al. (2002). Deep structure and mineral resources of Kazakhstan. Almaty: Oil and gas Handbook.

Davies, R. J., Almond, S., \& Ward, R. S., et al. (2014). Oil and gas wells and their integrity: Implications for shale and unconventional resource exploitation. Marine and Petroleum Geology. http://dx.doi.org/10.1016/j.marpetgeo.2014.03.001

Dumler, L. F., Roschin, I. N., \& Bilyalov, B. D. (1996). Coal-bearing basins of Kazakhstan. Karaganda: Geology and Mineral Resources of Kazakhstan, Vol. 1.

Glasby, G. P. (2006). Abiogenic origin of hydrocarbons: An historical overview. Resourse Geologe (Vol. 56, pp. 85-98).

Golitsyn, M. V., Dumler, L. F., Orlov, I. V., \& Maksimov, V. M. (1973). The main elements of the evolution of coal formation in Kazakhstan. Moscow: Nedra. Geology of coal and oil shale of the USSR, Vol. 5.

Honglin, L., Guizhong, L., Bo, W., Yibing, W., \& Yanxiang, L. (2011). High Coal Rank Exploration of Coalbed Methane and Its Distribution in China: In the proceedings of the International Coalbed Methane and Shale Gas Symposium (paper 0705, pp. 5-12).

Howarth, R.W. et al. (2011). Methane and greenhouse-gas footprint of natural gas from shale formations. 
Climatic Change Letters. http://dx.doi.org/10.1007/s10584-011-0061-5

Hower, T. L., Jones, J. E., Goldstein, D. M., \& Harbridge, W. (2003). Development of the Wyodak Coalbed Methane Resource in the Powder River Basin: Proceedings of the SPE Annual Technical Conference and Exhibition. (Paper SPE 84428). http://dx.doi.org/10.2118/84428-MS

King, G., \& King, D. (2013). Environmental risk arising from well construction failure: Differences between barrier failure and well failure, and estimates of failure frequency across common well types, locations and well age: Proceedings of the SPE meeting. New Orleans, LA, USA. http://dx.doi.org/10.2118/166142-MS

Kler, V. R. (1973). Geology of the Karaganda coal basin. Moscow: Nedra. Geology of coal and oil shale of the USSR, 9(1).

Kort, E. A., Eluszkiewicz, J., Stephens, B. B., \& Miller, J. B. et al. (2008). Emissions of $\mathrm{CH}_{4}$ and $\mathrm{N}_{2} \mathrm{O}$ over the United States and Canada based on a receptor-oriented modeling framework and COBRA-NA atmospheric observations. Geophysics Resources Letter, 35, L18808. http://dx.doi.org/10.1029/2008GL034031

Koubaichuk, Ju. (2004). Methane: inexhaustible possibilities. Karaganda: Industrial Karaganda, Vol. 7.

Kwon, S. S., \& Aliyev, S. B. (2003). Technical and technological solutions for enhancing the efficiency of coalbed in the Karaganda basin. Karaganda: Coal, 7, 10-11.

Mavor, M. J., Gunter, W. D., \& Robinson, J. R. (2004). Alberta Multiwell Micro-Pilot Testing for CBM Properties, Enhanced Methane Recovery and $\mathrm{CO}_{2}$ Storage Potential: Proceedings of the SPE Annual Technical Conference and Exhibition. (Paper SPE 59784). http://dx.doi.org/10.2118/59784-MS

Ministry of Industry and New Technologies of RoK. (2009). Innovative investment project "Methane" for 2010-2014. Astana, Kazakhstan: Ministry of Industry and New Technologies of RoK.

Mohaghegh, S. D., Nunsavathu, U. N., \& Jalal, J. et al. (2005). Development of a Series of National Coalbed Methane Databeses: Proceedings of the SPE Eastern Regional Meeting. (Paper SPE 90256). http://dx.doi.org/10.2118/98011-MS

Moore, C. W., Zielinska, B., Pétron, G., \& Jackson, R. B. (2014). Air impacts of increased natural gas acquisition, processing, and use: a critical review. Environmental Science and Technology. http://dx.doi.org/10.1021/es4053472

Olsen, T. N., Brezine, G., \& Frenzel, T. (2003). Improvement Processes for Coalbed Natural Gas Completion and Stimulation: Proceedings of the 2003 SPE Annual Technical Conference and Exhibition (paper SPE 84122). Denver, USA.

Palmer, I., Moschovidis, Z., \& Cameron, J. (2005). Coal Failure and Consequences for Coalbed Methane Wells: Proceedings of the SPE Annual Technical Conference and Exhibition. (Paper SPE 96872). http://dx.doi.org/10.2118/96872-MS

Puchkov, L. A., Slastunov, S. V., Present, G. M., \& Baimukhametov, S. K. (2003). Coalbed Methane - some challenges and directions of their solution. Karaganda: Coal, 12, 43-48.

Roberts, S., Charpentier, R. R., Cook, T., Klett, T. R., Pollastro, R. M., \& Schenk C. J. (2006). Assessment of coalbed gas resources in Cretaceous and Tertiary rocks on the North Slope, Alaska. Fact Sheet - U.S. Geological Survey Report, FS 2006-3105, pp. Retrieved February 4, 2014, from http://pubs.usgs.gov/fs/2006/3105/

Saginov, A. S., \& Li, K. D. (2006). On the commercial production of coalbed methane in the Republic of Kazakhstan. Publishing Office of Karaganda State Mining University, Vol. 2.

Sayers, A. C., Boyer, C. M., Frenzel, T. J., \& Rodgers, R. A. (2004). Technologies Key to Deep CBM Success. The American Oil and Gas Report, 47(3).

Schlumberger Data Processing and Consulting Services (DCS). (2013). "Zhumys-Strojservis" (Temco Energy Group). Karaganda, Kazakhstan: Schlumberger Data Processing and Consulting Services.

Stevens, S. H., \& Hadiyanto. (2004). Indonesia: Coalbed Methane Indicators and Basin Evaluation: Proceedings of the SPE Asia Pacific Oil and Gas Conference and Exhibition. (Paper SPE 88630). $\mathrm{http}: / / \mathrm{dx}$.doi.org/10.2118/88630-MS

The Presidential Decree №577 from 30 ${ }^{\text {th }}$ of May, 2013. Aqorda, Astana, Kazakhstan.

Tsang, C. F., Birkholzer, J., \& Rutqvist., J. (2008). A Comparative Review of Hydrologic Issues Involved in Geologic Storage of $\mathrm{CO} 2$ and Injection Disposal of Liquid Waste. Environment and Geology, 54(8), 
1723-1737. http://dx.doi.org/10.1007/s00254-007-0949-6

Vasuchkin, U. F. (1986). Physico-chemical methods of degassing of coal seams. Moscow: Nedra.

Vengosh, A., Jackson, R. B., Warner, N., Darrah, T. H., \& Kondash, A. (2014). A critical review of the risks to water resources from unconventional shale gas development and hydraulic fracturing in the United States. Environmental Science and Technology. http://dx.doi.org/10.1021/es405118y

Vidic, R. D., Brantley, S. L., Vandenbossche, J. M., Yoxtheimer, D., \& Abad, J. D. (2013). Impact of shale gas development on regional water quality. Science, 340(6134). http://dx.doi.org/10.1126/science.1235009

\section{Note}

Note 1. Geological map of Karaganda coal basin had been modified by the author, using up-to-date geological and geophysical data of LLP "Zhumys-Strojservis» (Temco Energy Group) for Schlumberger Data Processing and Consulting Services.

\section{Copyrights}

Copyright for this article is retained by the author(s), with first publication rights granted to the journal.

This is an open-access article distributed under the terms and conditions of the Creative Commons Attribution license (http://creativecommons.org/licenses/by/3.0/). 